\title{
UPAYA MENINGKATKAN MINAT BACA SEBAGAI SARANA UNTUK MENCERDASKAN BANGSA
}

\author{
Suharmono Kasiyun \\ Universitas Negeri Surabaya \\ Email: suharmono_ka@yahoo.com
}

\begin{abstract}
Abstrak
Tujuan kajian ini adalah untuk mencari alternatif meningkatkan minat baca di masyarakat, khususnya di kalangan sekolah, sebagai upaya untuk mengatasi rendahnya minat baca. Minat baca mempunyai pengaruh yang besar terhadap kemajuan suatu bangsa. Dibandingkan dengan beberapa negara tetangga, minat baca masyarakat Indonesia masih termasuk rendah. Minat baca menjadi kunci penting bagi kemajuan suatu bangsa, karena penguasaan Iptek hanya dapat diraih dengan minat baca yang tinggi. Aspek keluarga, masyarakat, dan lembaga pendidikan mempunyai peran penting dalam meningkatkan minat baca masyarakat. Upaya meningkatkan minat baca anak menjadi tanggungjawab bersama, antara pustakawan, guru, orang tua, dan masyarakat. Pustakawan dan guru sesuai dengan beban tugas yang disandangnya, mempunyai tanggung jawab langsung dalam meningkatkan minat baca. Dalam upaya meningkatkan minat baca, sebaiknya anak-anak diberi stimulan agar minat baca itu muncul dari diri murid itu sendiri. Upaya meningkatkan minat baca dengan memaksa siswa membaca buku sebanyak-banyaknya tidak akan efektif. Demikian juga tidak etis memaksa anak untuk membeli buku.
\end{abstract}

Kata Kunci: minat baca, pustakawan, lembaga pendidikan

\begin{abstract}
This study aims to find laternatif way to improve society's reading prolicity, particularly for school members, as a solution to overcome the low of reading. The reading prolicity has a great influence to the progress of the nation-state. Compare to the neighbor country, Indonesian reading prolicity is still low. It is a key to boost the progress because the capability of science and technology can be achieved through reading skills. Family, society, and educational institution have significant role in improving reading skills. It is responsible for all elements of society like librarian, teachers, parents, and society itselves. Librarian and teachers have direct responsible in improving that. To deal with that, it is good to give stimulant in gaining the reading tradition. The reading force is not effective for students. It is also unrecognized to force student to buy books.
\end{abstract}

Keywords: reading prolicity, librarian, educational institutions. 


\section{PENDAHULUAN}

Dalam kegiatan berbahasa, ada empat keterampilan berbahasa yang perlu dimiliki oleh semua orang, yaitu menyimak, berbicara, membaca, dan menulis. Keempat keterampilan berbahasa itu dapat dibedakan keterampilan berbahasa reseptif dan ke4terampilan berahasa produktif. Keterampilan berahasa reseptif meliputi menyimak dan membaca, sedang keterampilan berbahasa produktif terdiri atas berbicara dan menulis. Keempat keterampilan itu tidak langsung dikuasai oleh penutur ahasa, tetapi diperoleh secara bertahap. Pertama sejak bayi lahir (atau masih dalam kandungan?) bayi melakukan kegiatan menyimak, berlanjut wicara, membaca, dan menulis. Keempat tahap keterampilan berbahasa itu berkaitan erat dengan kualitas dan tingkat budaya suatu masyarakat. Masyarakat Indonesia dapat duduk semalam suntuk sambil mendengarkan pagelaran wayang kulit, namun tidak demikian dalam hal membaca.

Berdasarkan kegiatan membaca di masyarakat, tingkat kemampuan membaca dapat dibedakan atas tujuh tingkatan Sulistyo-Basuki (1991:7) membedakan tingkatan kemampuan membaca sebagai berikut: (1) orang yang tidak mampu membaca sama sekali; (2) orang yang memiliki kemampuan teratas dalam membaca; (3) orang yang sedang belajar dalam membaca; (4) orang yang melek huruf namun tidak membaca kecuali membaca bacaan terbatas pada kehidupan sehari-hari; (5) orang yang melek huruf namun bukan pembaca buku; (6) orang yang melek huruf namun bukan pembaca yang tetap; (7) orang yang melek huruf serta merupakan pembaca buku yang tetap.

Minat baca menjadi kunci penting bagi kemajuan suatu bangsa, karena penguasaan Iptek hanya dapat diraih dengan minat baca yang tinggi, bukan 80 | ISSN: 22477-5150 http://journal.unesa.ac.id/index.php/jpi 
kegiatan menyimak atau mendengarkan. Para petani di pedesaan akan mampu membuat tanamannya menjadi subur dan berproduksi melimpah ruah karena mendengarkan pengarahan dari petugas penyuluhan, namun mereka tidak akan dapat menghasilkan bibit unggul dan menciptakan teknologi pertanian yang canggih kalau tidak membaca.

Minat baca adalah keinginan atau kecenderungan hati yang tingggi (gairah) untuk membaca (Siregar, 2004 ). . Definisi itu sejalan dengan pendapat Darmono yang menyatakan bahwa minat baca merupakan kecenderungan jiwa yang mendorong sesseorang berbuat sesuatu terhadap membaca (Darmono, 2001: 182). Minat baca tumbuh dari pribadi masing-masing seseorang, sehingga untuk meningkatkan minat baca perlu kesadaran setiap individu. Negara-negara maju, adalah Negara yang minat bacamasyarakatnya tinggi. Oleh karena itu minat baca menduduki posisi penting bagi kemajuan suatu bangsa. Dibanding dengan Negara-negara yang tergabung dalam ASEAN dan negara asing lainnya, Indonesia masih menduduki urutan terbawah dalam hal minat baca. Di tingkat internasional, Indonesia memiliki indeks membaca 0,001. Hal itu berarti dalam setiap seribu orang, hanya satu orang yang memiliki minat baca tinggi. Kondisi itu jauh berbeda jika dibanding dengan Amerika yang memiliki indeks membaca 0,45 , dan Singapura 0,55 . Berdasarkan survey Unesco minat baca masyarakat Indonesia menduduki urutan 38 dari 39 negara yang diteliti. Laporan bank Dunia no.16369-IND (Education in Indonesi from Crisis to recovery) menyebutkan bahwa tingkat membaca usia kelas VI Sekolah Dasar di Indonesia hanya mampu meraih skor 51,7 di bawah Filipina $(52,6)$, Thailand $(65,1)$ dan Singapura (74,0).Data Badan Pusat Statistik tahun 2006 menunjukan bahwa penduduk Indonesia yang menjadikan baca sebagai sumber informasi baru 
sekitar 23,5\%. Sedangkan yang menonton televisi $85,9 \%$ dan mendengarkan radio $40,3 \%$.

Data lain menyebutkan (1) Berdasarkan studi lima tahunan yang dikeluarkan oleh Progress in International Reading Literacy Study (PIRLS) pada tahun 2006, yang melibatkan siswa sekolah dasar (SD), hanya menempatkan Indonesia pada posisi 36 dari 40 negara yang dijadikan sampel penelitian. Posisi Indonesia itu lebih baik dari Qatar, Kuwait, Maroko, dan Afrika Selatan," ujar Ketua Center for Social Marketing (CSM), Yanti Sugarda di Jakarta, Rabu (7/7); (2) Penelitian Human Development Index (HDI) yang dikeluarkan oleh UNDP untuk melek huruf pada 2002, menempatkan Indonesia pada posisi 110 dari 173 negara. Posisi tersebut kemudian turun satu tingkat menjadi 111 di tahun 2009. (3) Berdasarkan data CSM, yang lebih menyedihkan lagi perbandingan jumlah buku yang dibaca siswa SMA di 13 negara, termasuk Indonesia. Di Amerika Serikat, jumlah buku yang wajib dibaca sebanyak 32 judul buku, Belanda 30 buku, Prancis 30 buku, Jepang 22 buku, Swiss 15 buku, Kanada 13 buku, Rusia 12 buku, Brunei 7 buku, Singapura 6 buku, Thailand 5 buku, dan Indonesia 0 buku. (4) Kompas (Kamis, 18 Juni 2009) menyatakan budaya baca masyarakat Indonesia menempati posisi terendah dari 52 negara di kawasan Asia Timur berdasarkan data yang dilansir Organisasi Pengembangan Kerja sama Ekonomi (OECD), kata Kepala Arsip dan Perpustakaan Kota Surabaya Arini. Saat berbicara dalam seminar "Libraries and Democracy" digelar Perpustakaan Universitas Kristen (UK) Petra Surabaya bersama Goethe-Institut Indonesien dan Ikatan Sarjana IImu Perpustakaan dan Informasi Indonesia (ISIPII) di Surabaya, Rabu, dia mengatakan, OECD juga mencatat 34,5 persen masyarakat Indonesia masih buta huruf.

82 | ISSN: 22477-5150 http://journal.unesa.ac.id/index.php/jpi 


\section{Fungsi, Manfaat, dan Tujuan Membaca}

Seseorang melakukan kegiatan membaca tentu mengharapkan sesuatu dari teks yang dibacanya, karena membaca mempunyai fungsi, manfaat, dan tujuan. Secara umum membaca berfungsi menyerap informasi dari teks yang dibacanya. Teks yang baik akan memberikan manfaat yang baik pula, memberikan pengetahuan dan pencerahan bagi pembacanya. Adapun tujuan membaca seperti dikemukakan Darmono (2001: 183) adalah sebagai berikut: (1) membaca untuk tujuan kesenangan; (2) membaca untuk meningkatkan pengetahuan; (3) membaca untuk melakukan suatu pekerjaan.

Orang dalam segala hal selalu membaca, baik membaca papan nama, spanduk, atau tulisan di rambu lalulintas. Namun bukan seperti itu kegiatan membaca yang dimaksudkan, melainkan dalam kegiatan membaca wacana teks. Kegiatan membaca untuk tujuan kesenangan adalah membaca yang bersifat rekreatif. Membaca rekreatif seperti kebanyakan masyarakat membaca karya sastra, baik berupa puisi, cerpen, atau novel. Mereka membaca karya sastra sebagai hiburan. Namun dalam membaca karya sastra tidak selalu bertujuan untuk kesenangan atau bersifat rekreatif. Kritikus sastra atau mahasiswa fakultas sastra biasa membaca karya sastra untuk melakukan penelitian terhadap karya sastra yang dibacanya.

Membaca untuk meningkatkan pengetahuan dapat dilakukan oleh siapa saja, dengan cara melakukan kegiatan membaca wacana ilmu pengetahuan. Bidang ilmu mempunyai cakupan yang luas, sehingga semakin tinggi pendidikan seseorang akan merasakan semakin banyak yang tidak diketahui. Kegiatan membaca ini merupakan kegiatan membaca yang dapat meningkatkan SDM. Guru dan pustakawan dengandalam profesi yang berhubungan langsung dengan 
masyarakat mempunyai tanggung jawab moral meningkatkan dan memasyarakatkan minat baca masyarakat. Membaca untuk melakukan pekerjaan lazim dilakukan di kantor-kantor baik kantor pemerintah maupun swasta. Kegiatan membaca untuk melakukan pekerjaan biasanya dilakukan secara rutin.

Meningkatnya minat baca akan meningkatkan kualitas sumber daya manusia. Guru dan pustakawan merupakan ujung tombak dalam meningkatkan minat baca masyarakat. Perpustakaan bukan sekedar konsumsi pelajar dan mahsiswa. Oleh karena itu berbagai upaya harus diusahakan untuk meningkatkan minat baca masyarakat.

\section{PENYEBAB RENDAHNYA MINAT BACA}

Tradisi membaca bukanlah tradisi nenek moyang yang diwariskan pada generasi sekarang. Tradisi yang ada sebagai peninggalan nenek moyang adalah tradisi menyimak atau mendengarkan. Seperti sudah diungkapkan di atas, masyarakat Indonesia khususnya di Jawa dapat betahan semalam suntuk menyaksikan pagelaran wayang, namun tidak demikian dalam membaca. Tradisi macapat di Jawa sebuah buku dibaca seseorang dalam situasi tertentu, dan disimak oleh banyak orang. Tradisi di Jawa saat kelahiran bayi, dibacakan Serat Yusuf, dan disimak oleh banyak orang. Karya tulis seperti Mahabharata dan serat Menak justru menjadi popular setelah diangkat ke dalam sastra lisan dalam pagelaran wayang dan kentrung.

Indonesia juga relatif belum lama dinyatakan bebas dari buta huruf. Sistem pemerintahan penjajah tidak memungkinkan masyarakat dapat membaca, terutamahuruf latin. Pemerintah Belanda baru menyelenggarakan pendidikan formal untuk kaum pribumi setelah menyelenggarakan Politik Etisch 84 | ISSN: 22477-5150 http://journal.unesa.ac.id/index.php/jpi 
pada tahun 1848. Pendidikan formal itu pun baru terbatas untuk kaum bangsawan. Antara tahun 1960 - 1970 pemerintah gencar melaksanakan pemberantasan buta huruf,

Pada tahun 1960-an minat baca generasi muda sebenarnya sudah lumayan baik, meskipun masih sebatas pada bacaan ringan. Anak-anak muda dalam segala kegiatan banyak yang membawa komik atau novel dan setelah dibaca kemudian saling menukar dengan temannya. Taman juga bacaan bermunculan di setiap kota, menyewakan bacaan novel maupun komik. Tokoh novel menjadi bahan pembicaraan pada saat mereka berkumpul. Cerita silat seperti Naga Sasra Sabuk Inten, dan Api di Bukit Menoreh selalu ditunggu terbutnya oleh masyarakat awam sampai pejabat. Namun gejala peningkatan minat baca itu kemudian menjadi surut dengan cepat seiring munculnya televisi swasta. Kesibukan membaca kembali beralih pada kegiatan menyaksikan tayangan televisi atau mendengarkan rekaman kaset akibat kemajuan teknologi. Satu demi satu taman bacaan pun mengalami kebangkrutan. Amat disayangkan masyarakat Indonesia yang bau "terbebas dari buta huruf" dan melangkah untuk menuju minat baca tiba-tiba terputus, dan dalam kehidupan sehari-harinya kembali dalam kegiatan mendengarkan.

Hardjoprakosa (2005 : 145) menyatakan bahwa ada beberapa hal yang menyebabkan rendahnya minat baca, yaitu (1) Pemerintah dan swasta dengan lembaga pendidikannya, para guru kurang memotivasi para anak didiknya untuk membaca buku-buku selain buku pelajaran; (2) Para orang tua tidak memberi dorongan kepada anak untuk mengutamakan membeli buku dari pada mainan, alat pandang dengar. Mereka biasanya kurang mengetahui jenis buku yang sesuai dan disukai anak, dan mereka biasanya juga kurang memperkenalkan 
perpustakan kepada anak-anak; (3) Para penerbit media cetak memasang harga buku yang bermutu terlalu tinggi, sehingga tak terjangkau oleh masyarakat luas; (4) Para pengarang, penyadur dan penerjemah yang semakin berkurang, karena royalti yang tidak menentu dan masih terkena PPH; (5) Perpustakaan Umum yang jumlahnya belum mencukupi di tiap Propinsi untuk melayani masyarakat; (6) Perpustakaan masjid yang belum terkelola dengan profesional.

\section{UPAYA UNTUK MENINGKATKAN MINAT BACA}

Upaya dalam meningkatkan minat baca masyarakat tidak dapat dibebankan pada keluarga saja, masyarakat saja, atau lembaga pendidikan saja. Aspek keluarga, masyarakat, dan lembaga pendidikan mempunyai peran penting dalam meningkatkan minat baca masyarakat. Ketiga aspek itu perlu dilakukan bersamaan. Guru dan pustakawan berperan penting dalam meningkatkan minat baca baca peserta didik maupun masyarakat. Agar dapat berperan meningkatkan minat baca, guru dan pustakawan harus mempunyai minat baca yang tinggi. Keteladanan perlu diberikan kepada masyarakat. Apabila guru dan pustakawan tidak memiliki minat baca yang tinggi, mustahil dapat menjalankan tugasnya dalam meningkatkan minat baca. Ratnaningsih dalam (dalam Koswara, 1998 : 300) menyatakan Peran proaktif pustakawan berkaitan dengan upaya menumbuhkan minat baca masyarakat sejak dini, memang utamanya dilakukan oleh pustakawan yang bekerja di perpustakaan yang melayani anak-anak. Pustakawan harus mampu mengajar, membimbing, serta memberi contoh pada anak-anak. Demikian pula guru yang berhadapan langsung dengan anak didik kegiatan mengajar, membimbing, dan memberl contoh dalam kegiatan minat baca tidak kalah pentingnya dari pustakawan. 


\section{Lingkungan rumah}

Sebagian besar waktu anak adalah di rumah, berumpul bersama keluarga. Untuk meningkatkan minat baca dapat dimulai sejak anak masih balita belum dapat membaca. Dalam hal ini peran keluarga sangat penting. Kegiatan yang dapat dilakukan di tengah keluarga adalah (1) mendongeng; (2) tersedianya bacaan di rumah, (3) mendiskusikan isi buku yang dibaca, (4) mengunjungi toko buku, (5) membiasakan memberi hadiah buku.

(1) Kegiatan Mendongeng

Kegiatan mendongeng biasanya dilakukan oleh ayah, ibu, kakek, atau nenek terhadap anak balita yang masih belum lancar membaca. Lazimnya kegiatan mendongeng dilakukan saat anak menjelang tidur malam. Kegiatan mendongeng penting untuk mengembangkan imajinasi anak dan memupuk rasa ingin tahu anak. Dalam hal ini pendongeng perlu memilih materi yang sesuai dengan anak. Dongeng tentang kancil, tupai, atau sejenisnya saat ini asing bagi anak, karena sudah anak-anak, terutama anak perkotaan jarang yang mengenal binatang itu. Masalah yang timbul dalam mendongeng biasanya pendongeng kehabisan materi dongeng, karena kegiatan mendongeng dilakukan hampir setiap malam. Untuk mengatasi hal itu pendongeng bisamembacakan buku.

(2) Tersedianya bacaan di rumah

Anak-anak atau orang tua akan membaca jika ada bahan bacaan. Untuk membuat anak-anak gemar membaca, orang tuanya pun harus gemar membaca. Setidak-tidaknya orang tua menyediakan bahan bacaan di rumah. Bahan bacaan dapat berupa buku, majalah, atau surat kabar. Dewasa ini berlangganan surat kabar relatif murah, namun sebagian masyarakat masih lebih mementingkan hal 
lain seperti pulsa sebagai media komunikasi daripada surat kabar. Keuntungan berlangganan surat kabar, satu surat kabar bisa dibaca oleh satu keluarga.

(3) Mendiskusikan isi buku yang dibaca

Kegiatan membaca dalam ilmu bahasa termasuk kegiatan reseptif, yaitu menyerap isi buku yang dibaca, sedang kegiatan wicara adalah kegiatan produktif. Kegiatan membaca sebaiknya diikuti dengan kegiatan berdiskusi, paing tidak orang tua di rumah bisa menanyakan tentang isi buku yang dibaca oleh anak-anak di rumah. Kalau buku itu merupakan buku konsumsi segala usia seperti buku keagamaan, atau buku tentang biografi seseorang, bisa didiskusikan dalam satu keluarga.

(4) Mengunjungi toko buku

Berekreasi tidak hanya ke tempat-tempat yang berpemandangan indah seperti gunung dan laut, toko buku bisa dijadikan sarana rekreasi. Anak-anak akan merasa senang diajak ke toko buku, karena di toko banyak pilihan. Di toko buku ada pula buku-buku yang tidak terbungkus plastik, dan dapat dibaca atau sekedar dilihat isinya. Dengan mengunjungi toko buku,dapat diketahui jika ada buku baru yang terbit.

(5) Memberi hadiah buku

Anak-anak saat berulang tahun biasanya diberi hadiah barang-barang yang berharga mahal, seperti pakaian, mainan, hp, atau diajak makan-makan di rumah makan. Kebiasaan member kado buku saat ulang tahun merupakan bagian kegiatan meningkatkan minat baca.Kegiatan itu lebih bernilai positif daripada sekadar memberikan hdiah barang-barang yang berharga mahal. Hardjoprakosa (2005 : 146) mengemukakan gagasan untuk meningkatkan minat baca, yaitu bahwa membaca harus dipromosikan sebagai kegiatan keluarga dan sekolah, sebaiknya dijadikan tradisi untuk memberi hadiah buku pada setiap 88 | ISSN: 22477-5150 http://journal.unesa.ac.id/index.php/jpi 
ulang tahun, naik kelas dan lainnya, mengajak anak ke toko buku untuk memberi kesempatan anak memilih sendiri buku yang diinginkan.

\section{Lingkungan Sosial}

Minat baca siswa dapat ditingkatkan berdasarkan hubungan sosial pembaca sebagai anggota masyarakat. Apabila tokoh-tokoh masyarakat dapat memberi keteladanan dalam minat baca, hal ini akan berpengaruh positif pada masyarakat. Minat baca masyarakat bisa dirintis melalui perpustakaanperpustakaan kecil di tempat-tempat pertemuan (berkumpul) masyarakat, seperti di masjid (perpustakaan masjid), di kantor RW, di pasar, di terminal, bandara, dan sebagainya. Sebagai contoh di Malioboro ada "perpustakaan" yang diangkut dalam gerobak dorong. Koleksi yang diangkut merupakan konsumsi untuk penjual souvenir, sambil berjualan mereka membaca koleksi “perpustakaan" gerobak dorong. Di beberapa masjid juga sudah menyelenggarakan perpustakaan kecil.

\section{Lembaga Pemerintah dan Swasta}

Lembaga pemerintah dan swasta mempunyai peran penting dalam meningkatkan minat baca masyarakat, terutama dengan cara menyelenggarakan perpustakaan, baik perpustakaan sekolah maupun perpustakaan khusus. Siregar (2004 : 97) menyatakan bahwa dalam rangka upaya meningkatkan minat baca masyarakat ada beberapa strategi yang dapat yang dapat ditempuh oleh pengelola perpustakaan. Strategi untuk meningkatkan minat baca itu antara lain: (1) Untuk Perpustakaan Sekolah : memperbaiki sistem pendidikan, fasilitas dan karakteristik pelayanan perpustakaan, dengan membuat 
kebijakan yang terkait dengan penetapan persentase jumlah anggaran belanja untuk perpustakaan yang harus dikeluarkan dari anggaran belanja sekolah ( sebesar dua atau tiga persen setiap tahun); (2) Untuk Perguruan Tinggi : memperbaiki fasilitas dan karakteristik pelayanan perpustakaan dan mengubah metode pengajaran dari teaching-based kepada learning-based. Peran perpustakaan harus diubah dari sekedar store house yang pasif menjadi educational house yang aktif. Reformasi perkuliahan akan mempunyai efek timbal balik pada perpustakaan, dan efek timbal balik yang sama akan dihasilkan dari bahan-bahan bacaan dan pelayanan perpustakaan yang disempurnakan; (3) Di Lingkungan Masyarakat : Perpustakaan Nasional dan Perpustakaan Daerah yang terdapat di setiap propinsi seharusnya dapat berperan lebih besar dalam mendorong dan menumbuhkan perpustakaan-perpustakaan umum tingkat Kecamatan, Desa dan Perpustakaan Masjid, agar pelayanan perpustakaan dapat menjangkau semua lapisan masyarakat.

Perbaikan sistem pendidikan selalu diupayakan oleh pemerintah, seperti memperbaiki kurikulum dan dan memperbaiki SDM dengan memberikan tunjangan bagi yang telah lolos PLPG, baik untuk guru negeri maupun swasta. Di dalam kurikulum '13 ada penekanan pada kompetensi inti 1 dan 2: KI 1 menghargai dan menghayati ajaran agama yang dianutnya ( $\mathrm{KI} 1$ dan $\mathrm{KI} 2$ ): yaitu menghargai dan menghayati ajaran agama yang dianutnya (KI 1), dan menghargai dan menghayati perilaku jujur, disiplin, tangungjawab, peduli (toleransi, gotong royong), santun, percaya diri, dalam berinteraksi secara efektif dengan lingkungan sosial dan alam dalam jangkauan pergaulan dan keberadaannya (dan KI 2). Kompetensi itu seharusnya lebih dulu dimiliki guru dan pustakawan sebelum guru mengajarkannya kepada siswa. Apabila guru dan pustakawan telah memiliki kedua kompetensi itu akan dapat berperan aktif 90 | ISSN: 22477-5150 http://journal.unesa.ac.id/index.php/jpi 
dalam meningkatkan minat baca. Anak-anak memerlukan figur yang dapat diteladani, bukan instruksi.

Perpustakaan selalu dikaitkan dengan minat baca, karena sumber bacaan berada di perpustakaan. Darmono (2001:188-189) menyatakan peran perpustakaan dalam menciptakan tumbuhnya kondisi minat baca di lingkungan sekolah sebagai berikut: (a) memilih bahan bacaan yang menarik bagi pengguna perpustakaan; (b) menganjurkan berbagai cara penyajian pelajaran dikaitkan dengan tugas-tugas di perpustakaan; (c) memberikan kemudahan dalam mendapatkan bacaan yang menarik untuk pengguna perpustakaan; (d) memberikan kebebasan membaca secara leluasa kepada pengguna perpustakaan; (e) perpustakaan perlu dikelola dengan baik agar pengguna merasa betah dan kerasan berkunjung ke perpustakaan; (f) perpustakaan perlu melakukan berbagai promosi kepada masyarakat berkaitan dengan peningkatan minat dan kegemaran membaca; (g) menanamkan kesadaran kepada pemakai perpustakaan ahwa membaca pendting dalamkehidupan; (h) melakukan berbagai kegiatan seperti minat dan kegemaran membaca untuk anak sekolah; (i) Mengaitkan bulan Mei sebagai Bulan Buku Nasional dengan melakukan kegiatan yang menunjang Bulan Buku Nasional; (j) memberikan penghargaan kepada siswa yang paling banyak meminjam buku

Banyak cara yang dapat diterapkan unuk meningkatkan minat baca, seperti yang dikemukakan oleh para pustawan. Hardjoprakosa (2005: 146) mengemukakan beberapa gagasan yang dapat diusahakan untuk meningkatkan minat baca seperti berikut: (1) Kegiatan mempromosikan buku sebagai bacaan yang menarik, sebaiknya penerbit bekerjasama dengan mass media seperti surat kabar, radio, TV untuk mempromosikan buku-buku berkualitas dengan harga 
terjangkau oleh masyarakat luas. Dan penerbit menerbitkan buku anak-anak dengan ilustrasi yang menarik dan harga terjangkau; (2) Peningkatan Fasilitas Perpustakaan dan Program Kegiatan Minat Baca, dengan menambah jumlah berbagai jenis perpustakaan ; Perpustakaan Daerah TK.II, Perpustakaan Keliling, Perpustakaan Sekolah, Perpustakaan Perguruan Tinggi, dan Perpustakaan Tempat Ibadah (Masjid, Gereja, Pura, dan Vihara).

Sesuai dengan pernyataan Hardjoprakosa di atas, penerbit dan mass media mempunyai peran penting dalam meningkatkan minat baca siswa. Semakin tinggi minat baca siswa dan masyarakat umum, akan membuat keuntungan penerbit dan mass media semakin besar. Penerbit dan mass media hendaknya juga membawa misi untuk mencerdaskan bangsa. Di Daerah Tk II sudah ada perpustakaan, tetapi kebanyakan pengelolaannya masih belum maksimal. Perpustakaan Keliling memang dapat membantu pembaca, namun keberadaannnya tidak konsisten.

Ratnaningsih (dalam Koswara, 1998 : 300) menyatakan peran proaktif pustakawan berkaitan dengan upaya menumbuhkan minat baca masyarakat sejak dini, memang utamanya dilakukan oleh pustakawan yang bekerja di perpustakaan yang melayani anak-anak. Pustakawan harus mampu mengajar, membimbing, serta memberi contoh pada anak-anak dengan cara: (1) Menata ruang baca anak sedemikian menarik, menyenangkan, dan nyaman, baik untuk kemudahan akses maupun interiornya agar anak tertarik untuk datang dan melihatnya; (2) Mengenalkan buku-buku gambar dan bacaan apa saja yang baik dan sesuai dengan jenjang usia dan pendidikan kelompok anak yang dibimbingnya; (3) Bercerita dari buku-buku yang baik dengan teknik yang menarik, untuk anak yang sudah dapat membaca tidak perlu sampai selesai ceritanya, kelanjutanya cerita tersebut disusruh menbaca sendiri. Sedangakan 92 | ISSN: 22477-5150 http://journal.unesa.ac.id/index.php/jpi 
bagi kelompok yang belum bisa membaca, cerita sebaiknya dibacakan sampai selesai agar mereka benar-benar mengetahui jalan ceritanya dan suatu ketika diminta untuk memerankan tokoh-tokoh dalam cerita tersebut, dengan bimbingan pustakawan; (4) Melatih anak untuk mencatat hal-hal yang menurut mereka menarik; (5) Menginstrusksikan pada anak untuk saling menukar catatan atau cerita antar kelompok kemudian masing-masing kelompok membacakan bagi kelompoknya; (6) Melatih mereka untuk membuat catatan harian secara rutin tentang kegiatan-kegiatan yang telah dilakukan; (7) Pustakawan dalam melakukan bimbingan dan latihan ini secara teratur, terjadwal, dan waktunya cukup.

Pendapat lain dikemukakan oleh Sukarman Kartosedono bahwa ada beberapa faktor yang dapat mempengaruhi pertumbuhan minat baca pada masyarakat, khususnya pada anak, yaitu: (1) Tersedianya pilihan yang luas atas bahan bacaan anak; (2) Tersedianya buku-buku anak di rumah, di sekolah, perpustakaan maupun toko buku; (3) Seleksi yang dilakukan oleh pustakawan untuk atau atas nama kebutuhan anak-anak; (4) Tersedianya waktu dan kesempatan anak-anak untuk membaca; (5) Kebutuhan dan kemampuan pribadi dari anak-anak itu sendiri (Kartosedono, 1998: 316).

\section{SIMPULAN}

Upaya meningkatkan minat baca anak menjadi tanggungjawab bersama, antara pustakawan, guru, orang tua, dan masyarakat. Nanum demikian pustakawan dan guru sesuai dengan beban tugas yang disandangnya, mempunyai tanggung jawab langsung dalam meningkatkan minat baca. Dalam upaya meningkatkan minat baca, sebaiknya anak-anak diberi stimulan agar minat 
baca itu muncul dari diri murid itu sendiri. Upaya meningkatkan minat baca dengan memaksa siswa membaca buku sebanyak-banyaknya tidak akan efektif. Demikian juga tidak etis memaksa anak untuk membeli buku.

Di lembaga pendidikan fasilitas yang baik diperlukan untuk meningkatkan minat baca, baik fasilitas ruangan maupun kelengkapan koleksi di perpustakaan. . Di samping itu juga diperlukan adanya kerja sama yang baik antara pustakawan dengan guru atau dengan dosen. Tempat perpustakaan yang terpencil di sudut sekolah membuat anak-anak enggan berkunjung ke perpustakaan. Anak-anak perlu keteladanan. Membaca juga berkaitan erat dengan menulis. Sekolah perlu menyediakan fasilitas seperti majalah dinding dan majalah sekolah untuk para siswa. Media itu mempunyai peran penting dalam mengekspresikan hasilminat baca melalui kegiatan karya tulis, karena siswa yang suka menulis secara tidak langsung juga suka membaca. Dan yang tidak kalah pentingnya adalah ketersediaan buku yang sesuai dengan kebutuhan pembaca.

\section{DAFTAR PUSTAKA}

Darmono. 2001. Manajemen Perpustakaan Sekolah. Jakarta: Grasindo.

Hardjoprakosa, Mastini , 2005. Bunga Rampai Kepustakawanan. Jakarta :

Perpustakaan Nasional RI.

Koswara, Engkos (editor) 2005 , Dinamika Informasi dalam Era Global. Bandung : IPI dan Remadja Rosdakarya.

Nasution, A.S. dkk. 1987. Perpustakaan Sekolah. Jakarta: Pusat Pembinaan Perpustakaan Depdikbud.

Siregar, A. Ridwan, 2004. Perpustakaan Energi Pembangunan Bangsa. Medan : Universitas Sumatera Utara,

94 | ISSN: 22477-5150 http://journal.unesa.ac.id/index.php/jpi 
Suharmono Kasiyun, Upaya Meningkatkan Minat Baca ...(hal. 79-95)

Sulistyo-Basuki. 1991. Pengantar Ilmu Perpustakaan. Jakarta: Gramedia

Staf Pengajar SMP Stella Duce Tarakanita Yogyakarta. 1994. Membina Perpustakaan Sekolah. Yogyakarta: Kanisius.

Sujanto M.S., J. Ch. 1988. Keterampilan Berbahasa Membaca - Menulis Bericara untuk Mata Kuliah Dasar Umum Bahasa Indonesia. Jakarta: Depdikbud.

Tarigan, Henry Gntur. 1986. Membaca: Seagai Suatu Keterampilan Berbahasa. Bandung: Angkasa.

Tim Penulis MPK Bahasa Indonesia. 2011. Menulis Ilmiah:Buku Ajar MPK Bahasa Indonesia. Suraaya: Unesa University Press. 